\title{
Cancer Therapy with Common Education
}

\author{
Gonghuang Cheng* \\ Department of Fisheries, Guangdong Ocean University, China
}

Submission: December 06, 2017; Published: December 15, 2017

"Correspondence Address: Gonghuang Cheng, Department of Fisheries, Guangdong Ocean University, Zhanjiang Guangdong China, Email: ghcheng@sohu.com

\section{Short Communication}

\section{About cancer and its origin}

\section{a. Normal Regeneration}

If our skin is broken and there will be bleeding. This indicates that the epithelial tissue is damaged, which requires the automatic repair of the body. That is to say that the epithelium around the wound begins to grow and cover the wound, as this regeneration is a normal in our body.

\section{b. Hyperplasia}

Proliferation, which refers to the emergence of redundant new tissues when the organization is regenerated. For example, the proliferation of common esophageal tissue, which affects our swallowing, causes obstruction and uncomfortable sensation in the larynx. Diet can be affected.

\section{c. Tumors generally refer to benign proliferation, and cancer is malignant}

Tumor is an abnormal mass in one part of the body, or abnormal hyperplasia of some tissues. For example, the common uterine myoma in the female reproductive system is a kind of tumor, which is generally benign. But if there is an abnormal condition, it may turn into a malignant tumor. The medical term for cancer refers to the malignant tumor of the epithelial tissue. Its characteristic is that the fast growth rate and the boundary between the tumor cells and the normal tissue are not obvious. The tumor cells are transferred to other tissues or organs with the blood flow and lymph. For example, liver cancer is transferred to other organs such as brain, lung, kidney and other organs. Lethality of cancer is very strong. Sometimes we call malignant tumors cancer, takes lymphosarcoma and leukemia for example. This is because we need general people known that the severity of the disease is similar to that of cancer.

\section{The basic concept of cancer in the secondary section}

Cancer is an abnormal proliferation of new organisms in our autologous tissue cells for some reason. In general, it is related to many factors such as lower body function (low immunity), heredity, other organisms (such as viruses, bacteria, parasites, etc.) infection. Precancerous lesions: refers to some related lesions that can easily lead to cancer. For example, the leukoplakia of the cervix is a precancerous lesion.

\section{a. Cancer can be produced in various organ tissues}

Types of cancer are common: lung cancer, gastric cancer, non Hodgkin's lymphoma, cervical cancer, brain cancer, colon cancer, colorectal cancer, ovarian cancer, leukemia, bone cancer, nasopharyngeal cancer, bladder cancer, breast cancer, renal carcinoma, lymphoma, pancreatic cancer, colorectal cancer, esophageal cancer and liver cancer. It can be seen that cancer can produce all kinds of tissues and organs in the body.

\section{b. Symptoms of cancers}

Generally speaking, pain, mass growth of tissue, fever-even high fever and weight loss are the most common symptoms of cancer because of the large number of cancer cells, energy consumption, ill mood, poor appetite. In addition, various cancers can cause different symptoms by affecting the function of their respective organs. Such as lung cancer, serious cough, phlegm with blood (silk), chest water; liver cancer (jaundice), gastric cancer (not diet) can cause massive bleeding; brain cancer caused paralysis.

\section{c. Cancers (of varying lengths)}

Generally speaking, cancer has been found at advanced stage, which is why we often recommend examination. Only by regular physical examination we can find out some abnormal conditions of the body in time and take Counter measures to achieve the purpose of keeping healthy. For cancer, if the precancerous lesions are found, timely treatment lucky.

\section{Prevention and Therapy}
a. Prevention is the first one
b. Exercise
c. No smoking and stop to take too much alcohol
d. Exposure to carcinogens as little as possible
e. Maintain a healthy and optimistic attitude
f. Diet attention: Not to eat or eat less pickled, smoked food, eat more and more vegetables, fruits, beans. 


\section{Cancer Therapy \& Oncology International Journal}

\section{Treatment}

For cancer treatment, we must pay attention to early detection of cancer. Surgery or the chemotherapy or radiotherapy can achieve the purpose of radical cure. The discovery is too late, only through comprehensive treatment to prolong life and alleviate pain for the patients. And mostly the therapy of cancer is surgery and radiation but these cannot help the patients much more especially for late case of cancers.

\section{Chinese medicine}

Traditional Chinese medicine believes that cancer is the accumulation of positive gas in the body and the accumulation of evil toxin. So, by means of health detoxification cancer prevention. The most useful Chinese herbs as follows can help to cure the cancer someway: Ginseng, Astragalus and Codonopsis, Poria, Atractylodes, angelica, Radix Pseudostellariae, yam, coix seed, medlar, Ligustrum lucidum, Psoralen; anticancer antidote: Hedyotis diffusa, Scutellaria barbata, tengligen, tuckahoe, buckwheat, dried toad skin, Bai Ying, Solanum nigrum, Duchesnea indica and Sophora flavescens; cancer food: asparagus, mushroom, Ganoderma lucidum, garlic etc..

\section{Suggestion}

Cancer can develop in anybody if the one is ill-in-immunity or by gene inheritance so we need to check our body regularly so as to discover the risk of cancer. We just take our good time with our relatives and take the disease with us without surgery if it was found to late so that we can get a good leisure before our leaving rather with so much treatment and low life quality.
Your next submission with Juniper Publishers will reach you the below assets

- Quality Editorial service

- Swift Peer Review

- Reprints availability

- E-prints Service

- Manuscript Podcast for convenient understanding

- Global attainment for your research

- Manuscript accessibility in different formats ( Pdf, E-pub, Full Text, Audio)

- Unceasing customer service

Track the below URL for one-step submission https://juniperpublishers.com/online-submission.php 